\title{
Effects of wheat source and particle size in meal and pelleted diets on finishing pig growth performance, carcass characteristics, and nutrient digestibility ${ }^{1,2}$
}

\author{
J. A. De Jong, * J. M. DeRouchey,* M. D. Tokach, ${ }^{*}$ S. S. Dritz, $\dagger$ \\ R. D. Goodband, $* 3$ C. B. Paulk, $* 4$ J. C. Woodworth, $*$ C. K. Jones, + and C. R. Stark \\ * Department of Animal Sciences and Industry, College of Agriculture, $\dagger$ Department \\ of Diagnostic Medicine/Pathobiology, College of Veterinary Medicine, and $\$$ Department \\ of Grain Sciences and Industry, College of Agriculture, Kansas State University, Manhattan 66506-0201
}

\begin{abstract}
Two experiments were conducted to test the effects of wheat source and particle size in meal and pelleted diets on finishing pig performance, carcass characteristics, and diet digestibility. In Exp. 1, pigs (PIC $327 \times 1050 ; n=288$; initially $43.8 \mathrm{~kg} \mathrm{BW}$ ) were balanced by initial BW and randomly allotted to 1 of 3 treatments with 8 pigs per pen ( 4 barrows and 4 gilts) and 12 pens per treatment. The 3 dietary treatments were hard red winter wheat ground with a hammer mill to 728,579 , or 326 $\mu \mathrm{m}$, respectively. From d 0 to 40, decreasing wheat particle size decreased (linear, $P<0.033$ ) ADFI but improved (quadratic, $P<0.014$ ) G:F. From d 40 to 83 , decreasing wheat particle size increased (quadratic, $P<0.018$ ) ADG and improved (linear, $P<0.002$ ) G:F. Overall from d 0 to 83 , reducing wheat particle size improved (linear, $P<0.002$ ) G:F. In Exp. 2, pigs (PIC $327 \times 1050 ; n=576$; initially $43.4 \pm 0.02 \mathrm{~kg}$ $\mathrm{BW})$ were used to determine the effects of wheat source and particle size of pelleted diets on finishing pig growth performance and carcass characteristics. Pigs were randomly allotted to pens, and pens of pigs were balanced by initial BW and randomly allotted
\end{abstract}

to 1 of 6 dietary treatments with 12 replications per treatment and 8 pigs/pen. The experimental diets used the same wheat-soybean meal formulation, with the 6 treatments using hard red winter or soft white winter wheat that were processed to 245,465 , and $693 \mu \mathrm{m}$ and 258, 402, and $710 \mu \mathrm{m}$, respectively. All diets were pelleted. Overall, feeding hard red winter wheat increased $(P<0.05)$ ADG and ADFI when compared with soft white winter wheat. There was a tendency $(P<0.10)$ for a quadratic particle size $\times$ wheat source interaction for ADG, ADFI, and both DM and GE digestibility, as they were decreased for pigs fed $465-\mu \mathrm{m}$ hard red winter wheat and were greatest for pigs fed $402-\mu \mathrm{m}$ soft white winter wheat. There were no main or interactive effects of particle size or wheat source on carcass characteristics. In summary, fine grinding hard red winter wheat fed in meal form improved G:F and nutrient digestibility, whereas reducing particle size of wheat from approximately 700 to $250 \mu \mathrm{m}$ in pelleted diets did not influence growth or carcass traits. Finally, feeding hard red winter wheat improved ADG and ADFI compared with feeding soft white winter wheat.

Key words: finishing pig, growth, hard red wheat, particle size, pellet, soft white wheat

\footnotetext{
${ }^{1}$ Contribution number 16p205-J from the Kansas Agric. Exp. Stn., Manhattan, KS 66506-0210.

${ }^{2}$ Funding, wholly or in part, was provided by The National Pork Board.

${ }^{3}$ Corresponding author: goodband@ksu.edu

${ }^{4}$ Present address: Department of Animal Science, 230 Kleberg, Texas A\&M University, College Station, TX 77843.

Received February 4, 2016.

Accepted May 13, 2016.
}

J. Anim. Sci. 2016.94:3303-3311 doi:10.2527/jas2016-0370

\section{INTRODUCTION}

Cereal grains for pigs historically have been ground to reduce particle size to improve digestibility and pig growth (Hancock and Behnke, 2001). Grinding currently occurs through a variety of different mill types ranging from roller mills to hammer mills with varying sizes of screens capable of producing a wide variety of particle sizes (Hancock and Behnke, 2001). 
Mavromichalis et al. (2000) observed that G:F was improved when wheat particle size was reduced either from 1,300 to $600 \mu \mathrm{m}$ or from 600 to $400 \mu \mathrm{m}$. Murphy et al. (2009) also reduced the particle size of wheat from 639 to $552 \mu \mathrm{m}$ and found that decreasing particle size of a pelleted wheat diet tended to improve G:F. Using estimated grinding costs, Healy et al. (1994) concluded that costs associated with grinding are justified through improvements in feed efficiency. Although numerous experiments have been conducted that investigated particle size reduction of corn (Wondra et al., 1995) and sorghum (Paulk et al., 2015), few studies have determined the effects of fine-grinding hard red or soft white wheat. In addition, little work has compared the feeding value of soft white wheat with that of hard red wheat.

Pelleting is another feed processing technology used throughout the swine industry. Stark et al. (1994) and Wondra et al. (1995) have shown that pelleting diets improved ADG and feed efficiency of finishing pigs, but data is limited in regards to the effect of reducing grain particle size in a pelleted diet. Therefore, the objectives of these experiments were to determine the effects of particle size of hard red and soft white wheat in pelleted diets and hard red winter wheat in meal diets on finishing pig performance, carcass characteristics, and nutrient digestibility.

\section{MATERIALS AND METHODS}

\section{General}

All practices and procedures used in this experiment were approved by the Kansas State University Institutional Animal Care and Use Committee. Both experiments were conducted at the Kansas State University Swine Teaching and Research Center, Manhattan, KS. Each pen ( 2.44 by $3.05 \mathrm{~m})$ contained a 2-hole, dry self-feeder (Farmweld, Teutopolis, IL) and a nipple-cup waterer to provide ad libitum access to feed and water. Pens had concrete slatted flooring with a deep pit for manure storage. Pigs were fed a common corn-soybean meal diet for approximately $10 \mathrm{~d}$ on entering the facility until pigs from both experiments reached their respective starting weights.

There were 8 pigs per pen, allowing for $0.93 \mathrm{~m}^{2} /$ pig. Daily feed additions to each pen were accomplished through a robotic feeding system (FeedPro; Feedlogic Corp., Willmar, MN) capable of providing and measuring feed amounts for individual pens. All diets for both experiments were manufactured at the O.H. Kruse Feed Technology Innovation Center at Kansas State University (Manhattan, KS).

\section{Chemical Analysis}

For both experiments, samples of wheat and soybean meal were collected at the feed mill. Samples of each diet were also collected from the farm, combined within phase, and subsampled. All ingredient and feed samples were analyzed for DM (method 934.01; AOAC, 2006), CP (method 990.03; AOAC, 2006), ether extract (method 920.39 A; AOAC, 2006), crude fiber (method 978.10; AOAC, 2006), ash (method 942.05; AOAC, 2006), Ca (method 965.14/985.01; AOAC, 2006), P (method 965.17/985.01; AOAC, 2006), starch method 15914; ISO, 2004), and ADF and NDF (Van Soest, 1963) at Ward Laboratories, Inc. (Kearney, NE). Initial samples of both of the wheat sources were analyzed for a complete AA profile (method 994.1247; AOAC, 2006) at University of Missouri Analytical Services (Columbia, MO).

\section{Physical Diet Analysis}

During both experiments, bulk density (Seedburo model 8800; Seedburo Equipment, Chicago, IL), particle size, and angle of repose of major ingredients and all meal diets were measured. Bulk density was determined for all ingredients using methods from Clementson et al. (2010). Particle size was determined using U.S. sieves, with numbers $6,8,12,16,20,30,40,50,70,100,140$, 200, and 270 and a pan. A Ro-Tap shaker (W.S. Tyler, Mentor, $\mathrm{OH}$ ) was used to sift the 100-g samples for 10 min. Particle size was conducted without or with a flow agent (amorphous silica powder; Gilson Company Inc., Middleton, WI), which was added at 0.5 to $100 \mathrm{~g}$ of feed. A geometric mean particle size and the log normal $\mathrm{SD}$ were calculated by measuring the amount of grain remaining on each screen (ASAE, 2008). Angle of repose was measured by allowing feed to flow freely over a flat circular platform of a known diameter (Appel, 1994). The diameter of the platform and height of the resulting pile were used to calculate the angle of repose. For pelleted diets, pellet durability index (PDI) was determined using a Holmen NHP100 (Tekpro Limited, Norfolk, UK) for $30 \mathrm{~s}$. Percentage fines were also determined with fines characterized as material that would pass through a number 6 Tyler sieve $(3,360-\mu \mathrm{m}$ opening) during $15 \mathrm{sec}$ of manual shaking (ASAE, 1987).

\section{Animals and Diets}

For both experiments, pigs were weighed approximately every 2 wk and feed disappearance was measured to determine ADG, ADFI, and G:F. On d 7 of phase 3 (d 67 in Exp 1 and d 61 and 59 in Exp. 2), fecal samples were collected from 2 pigs per pen. Phase 3 diets contained $0.5 \%$ titanium dioxide as an indigestible 
marker. After collection, fecal samples were dried at $50^{\circ} \mathrm{C}$ in a forced-air drying oven (Precision Scientific Inc., Chicago, IL) and then ground for analysis of GE and titanium concentration. The digestibility values were calculated using the index method (Kong and Adeola, 2014).

In Exp. 1, a total of 288 pigs (PIC $327 \times 1050$; initially $43.8 \mathrm{~kg} \mathrm{BW}$ ) were used in an 83-d study. Pigs were balanced by initial BW and randomly allotted to 1 of 3 treatments with 8 pigs per pen and 12 pens per treatment. Diets were fed in 3 phases in meal form from $\mathrm{d} 0$ to $27, \mathrm{~d} 27$ to 60 , and $\mathrm{d} 60$ to 83 . The 3 dietary treatments were hard red winter wheat ground to 728 , 579 , and $326 \mu \mathrm{m}$, respectively. Wheat was ground to the 3 particle sizes using a full-circle teardrop hammer mill (Bliss 22115; Bliss Industries LLC, Ponca City, OK) equipped with a number 12,8 , or 4 screen $(4.83$, 3.30 , and $1.52 \mathrm{~mm}$, respectively).

In Exp. 2, a total of 576 pigs (PIC $327 \times 1050$; initially $43.4 \pm 0.02 \mathrm{~kg} \mathrm{BW}$ ) from 2 consecutive finishing groups were used. Pigs were randomly allotted to pens on entry into the finisher facility. Pens of pigs were balanced by initial BW and randomly allotted to 1 of 6 dietary treatments with 12 replications per treatment and 8 pigs per pen. The experimental diets all had the same wheat-soybean meal formulation, with the 6 treatments formed by including the wheat from 1 of 2 sources (hard red winter, the same batch as in Exp. 1, vs. soft white winter) that were processed to 3 different mean particle sizes $(245,465$, and $693 \mu \mathrm{m}$ and 258, 402, and $710 \mu \mathrm{m}$, respectively). All diets were fed in pelleted form.

The 3 particle sizes of the hard red winter wheat were created with a number 2,10 , or 16 screen $(1.00$, 4.06 , and $6.35 \mathrm{~mm}$, respectively). The hard red wheat ground to $245 \mu \mathrm{m}$ was first ground through a 3-high roller mill (model 924; RMS Roller-Grinder, Harrisburg, $\mathrm{SD})$ to ensure a fine enough grind was achieved through the hammer mill. Soft white wheat was ground through number 4, 12, and 16 hammer mill screens $(1.52,4.83$, and $6.35 \mathrm{~mm}$, respectively). Diets were all pelleted through pellet mill (30 HD Master Model; California Pellet Mill, San Francisco, CA). Pellets were steam conditioned at $85^{\circ} \mathrm{C}$. Pellets were approximately $4 \mathrm{~mm}$ in diameter and $15 \mathrm{~mm}$ in length. During the grinding and pelleting process, electrical consumption and throughput were measured.

Before marketing, all pigs were individually weighed and tattooed for carcass data collection and transported approximately $200 \mathrm{~km}$ to a commercial abattoir (Triumph Foods LLC, St. Joseph, MO). All pigs were marketed on the same day within each experiment. Standard carcass characteristics including HCW, percentage carcass yield, backfat, loin depth, and percentage lean were measured. Carcass yield was calculated
Table 1. Chemical and AA analysis of wheat sources (as-fed basis) ${ }^{1}$

\begin{tabular}{|c|c|c|}
\hline Item, $\%$ & Hard red winter wheat & Soft white winter wheat \\
\hline$\overline{\mathrm{DM}}$ & 90.86 & 91.80 \\
\hline $\mathrm{CP}$ & 11.8 & 11.2 \\
\hline $\mathrm{ADF}$ & 3.2 & 2.8 \\
\hline NDF & 8.1 & 8.6 \\
\hline $\mathrm{Ca}$ & 0.07 & 0.13 \\
\hline $\mathrm{P}$ & 0.38 & 0.40 \\
\hline Ether extract & 1.8 & 1.6 \\
\hline Ash & 1.81 & 1.89 \\
\hline $\operatorname{Starch}^{2}$ & 55.4 & 56.9 \\
\hline \multicolumn{3}{|l|}{$\mathrm{AA}, \%$} \\
\hline Lys & 0.40 & 0.40 \\
\hline Ile & 0.41 & 0.44 \\
\hline Met & 0.21 & 0.20 \\
\hline Met + Cys & 0.48 & 0.48 \\
\hline Thr & 0.36 & 0.34 \\
\hline Trp & 0.17 & 0.15 \\
\hline Val & 0.47 & 0.52 \\
\hline
\end{tabular}

${ }^{1}$ A composite sample consisting of 6 subsamples was used for analysis. The same batch of hard red winter wheat was used in both Exp. 1 and 2.

${ }^{2}$ Measured only available starch.

by dividing the HCW at the plant by the live weight at the farm before transport to the plant. Fat depth and loin depth were measured with an optical probe inserted between the third and fourth last rib (counting from the ham end of the carcass) at a distance approximately $7 \mathrm{~cm}$ from the dorsal midline. Jowl fat samples were collected and analyzed by near-infrared spectroscopy (MPA, Bruker Corp., Bremen, Germany) for iodine value using the equation of Cocciardi et al. (2009).

\section{Statistical Analysis}

Data were analyzed as a completely randomized design using PROC MIXED in SAS (SAS Inst. Inc., Cary, NC) with pen as the experimental unit. All treatment means were analyzed using the LSMEANS statement. For Exp. 1, linear and quadratic contrasts were completed to determine the effects of decreasing wheat particle size. For Exp. 2, linear and quadratic contrasts were completed to determine the main effects of decreasing wheat particle size as well as the interaction with wheat source. The main effect of wheat source was also determined. Linear and quadratic contrasts within wheat source for particle size were also tested. Lastly, there was no interaction between the 2 groups of pigs used and, therefore, group was used as a random effect. For both experiments, polynomial contrast coefficients were adjusted for unequally spaced treatments using the IML procedure of SAS. Results were considered significant at $P \leq 0.05$ and were considered tendencies between $P>0.05$ and $P \leq 0.10$. 


\section{RESULTS}

\section{Chemical Analysis}

Chemical and AA analysis were generally similar for the hard red and soft white winter wheat (Table 1). Due to the similarities in AA analysis between sources, the values for the hard red winter wheat were used for both wheat sources in formulation using NRC (2012) standardized ileal digestibility AA coefficients. Analysis of the treatment diets showed that formulated values and chemical analysis (Tables 2 and 3) were similar.

\section{Physical Analysis}

Physical analysis of ground wheat and complete diets in Exp. 1 (Table 4) revealed that, as expected, as the wheat particle size decreased, the particle size of the diet decreased as well, which led to an increase in the diet angle of repose. Using a flow agent during particle size analysis revealed a numerical reduction of up to $40 \mu \mathrm{m}$ when compared with analysis without a flow agent. Diet analysis from Exp. 2 (Table 5) revealed that increasing the particle size of wheat regardless of the source worsened PDI values but had no effect on bulk density or percentage fines of the diets. Grinding hard red winter wheat required more kilowatt hours per tonne than grinding soft white winter wheat (Table 6). Finely ground wheat increased kilowatt hours per tonne for hard red wheat during pelleting but did not influence kilowatt hours per tonne for soft white wheat. Throughput during pelleting was improved by increasing wheat particle size as well as by pelleting soft white wheat compared with hard red wheat.

\section{Growth, Carcass, and Digestibility}

In Exp. 1, from d 0 to 40, decreasing wheat particle size decreased (linear, $P<0.038$ ) ADFI but improved (quadratic, $P<0.006$ ) G:F (Table 7). From d 40 to 83, decreasing wheat particle size increased (quadratic, $P<0.013$ ) ADG and increased (linear, $P<0.001) \mathrm{G}$ :F. Overall from d 0 to 83 , reducing wheat particle size increased (linear, $P<0.002$ ) G:F with no difference in ADG or ADFI observed. Finally, reducing wheat particle size increased (linear, $P<0.05$ ) DM and GE digestibility.

In Exp. 2, feeding hard red winter wheat improved $(P<0.05)$ ADG and ADFI when compared with pigs fed soft white winter wheat (Table 8$)$. There was a tendency $(P<0.10)$ for a quadratic particle size $\times$ wheat source interaction for ADG and ADFI and a significant interaction $(P<0.05)$ for both DM and GE digestibility because ADG, ADFI, and both DM and GE digestibility values decreased in pigs fed $465-\mu \mathrm{m}$ hard red winter wheat but increased for those fed $402-\mu \mathrm{m}$ soft white
Table 2. Diet composition, Exp. 1 (as-fed basis)

\begin{tabular}{|c|c|c|c|}
\hline \multirow[b]{2}{*}{ Item } & \multicolumn{3}{|c|}{$\mathrm{BW}$ range, $\mathrm{kg}$} \\
\hline & 44 to 63 & 63 to 82 & 82 to 120 \\
\hline \multicolumn{4}{|l|}{ Ingredient, \% } \\
\hline Hard red wheat & 81.26 & 87.43 & 92.18 \\
\hline Soybean meal $(46.5 \% \mathrm{CP})$ & 15.84 & 10.14 & 4.94 \\
\hline Calcium phosphate $(21.5 \% \mathrm{P})$ & 0.28 & 0.03 & - \\
\hline Limestone & 1.43 & 1.28 & 1.30 \\
\hline Salt & 0.35 & 0.35 & 0.35 \\
\hline Vitamin and trace mineral premix ${ }^{1,2}$ & 0.30 & 0.25 & 0.20 \\
\hline Phytase $^{3}$ & 0.08 & 0.08 & 0.05 \\
\hline L-Lys HCl & 0.33 & 0.33 & 0.35 \\
\hline DL-Met & 0.04 & 0.02 & 0.02 \\
\hline L-Thr & 0.09 & 0.09 & 0.11 \\
\hline Titanium dioxide ${ }^{4}$ & - & - & 0.50 \\
\hline \multicolumn{4}{|l|}{ Calculated analysis } \\
\hline \multicolumn{4}{|l|}{ Standard ileal digestible (SID) AA, \% } \\
\hline Lys & 0.94 & 0.81 & 0.71 \\
\hline Ile:Lys & 64 & 63 & 61 \\
\hline Met:Lys & 30 & 30 & 30 \\
\hline Met + Cys:Lys & 61 & 63 & 66 \\
\hline Thr:Lys & 62 & 63 & 66 \\
\hline Trp:Lys & 23.1 & 23.7 & 23.7 \\
\hline Val:Lys & 68 & 69 & 67 \\
\hline Total Lys, \% & 1.05 & 0.91 & 0.79 \\
\hline $\mathrm{ME},{ }^{5} \mathrm{kcal} / \mathrm{kg}$ & 3,154 & 3,163 & 3,163 \\
\hline $\mathrm{NE},{ }^{6} \mathrm{kcal} / \mathrm{kg}$ & 2,323 & 2,358 & 2,385 \\
\hline SID Lys:ME, g/Mcal & 2.98 & 2.56 & 2.24 \\
\hline Available P, \% & 0.30 & 0.25 & 0.24 \\
\hline \multicolumn{4}{|l|}{ Chemical analysis, $\%^{7}$} \\
\hline $\mathrm{DM}$ & 90.28 & 89.91 & 89.16 \\
\hline $\mathrm{CP}$ & 19.7 & 18.4 & 16.1 \\
\hline $\mathrm{ADF}$ & 2.9 & 2.8 & 2.5 \\
\hline NDF & 9.3 & 8.2 & 7.8 \\
\hline Crude fiber & 2.6 & 2.2 & 2.3 \\
\hline $\mathrm{Ca}$ & 0.74 & 0.89 & 0.74 \\
\hline $\mathrm{P}$ & 0.51 & 0.48 & 0.41 \\
\hline Ether extract & 1.4 & 1.5 & 1.6 \\
\hline Ash & 4.41 & 4.79 & 3.70 \\
\hline Starch & 44.1 & 45.0 & 51.3 \\
\hline
\end{tabular}

${ }^{1}$ Provided, per kilogram of premix, 4,409,200 IU vitamin A, 551,150 IU vitamin $\mathrm{D}_{3}, 17,637 \mathrm{IU}$ vitamin $\mathrm{E}, 1,764 \mathrm{mg}$ vitamin $\mathrm{K}, 3,307 \mathrm{mg}$ riboflavin, $11,023 \mathrm{mg}$ pantothenic acid, $19,841 \mathrm{mg}$ niacin, and $15.4 \mathrm{mg}$ vitamin $\mathrm{B}_{12}$.

${ }^{2}$ Provided, per kilogram of premix, $26.5 \mathrm{~g} \mathrm{Mn}$ from manganese oxide, $110 \mathrm{~g}$ Fe from iron sulfate, $110 \mathrm{~g} \mathrm{Zn}$ from zinc sulfate, $11 \mathrm{~g} \mathrm{Cu}$ from copper sulfate, $198 \mathrm{mg}$ I from calcium iodate, and $198 \mathrm{mg}$ Se from sodium selenite.

${ }^{3}$ Phyzyme 600 (Danisco Animal Nutrition, St. Louis, MO) provided 450.3 phytase units $/ \mathrm{kg}$ feed, with a release of $0.11 \%$ available $\mathrm{P}$.

${ }^{4}$ Titanium was included in the Phase 3 diet as an indigestible marker and was fed for the first $7 \mathrm{~d}$ of the phase at a level of $0.5 \%$ at the expense of corn.

${ }^{5} \mathrm{NRC}, 2012$.

${ }^{6}$ Sauvant et al., 2004.

${ }^{7} \mathrm{~A}$ composite sample consisting of 6 subsamples was used for analysis. 
Table 3. Diet composition, Exp. 2 (as-fed basis)

\begin{tabular}{|c|c|c|c|c|c|c|}
\hline \multirow[b]{3}{*}{ Item } & \multicolumn{6}{|c|}{ Wheat source and $\mathrm{BW}$ range, $\mathrm{kg}$} \\
\hline & \multicolumn{3}{|c|}{ Hard red winter wheat } & \multicolumn{3}{|c|}{ Soft white winter wheat } \\
\hline & 43 to 63 & 63 to 82 & 82 to 120 & 43 to 63 & 63 to 82 & 82 to 120 \\
\hline \multicolumn{7}{|l|}{ Ingredient, \% } \\
\hline Wheat & 78.44 & 85.01 & 89.43 & 78.44 & 85.01 & 89.43 \\
\hline Soybean meal $(46.5 \% \mathrm{CP})$ & 17.31 & 11.15 & 6.33 & 17.31 & 11.15 & 6.33 \\
\hline Choice white grease & 1.50 & 1.50 & 1.50 & 1.50 & 1.50 & 1.50 \\
\hline Calcium phosphate $(21.5 \% \mathrm{P})$ & 0.25 & - & - & 0.25 & - & - \\
\hline Limestone & 1.38 & 1.28 & 1.25 & 1.38 & 1.28 & 1.25 \\
\hline Salt & 0.35 & 0.35 & 0.35 & 0.35 & 0.35 & 0.35 \\
\hline Vitamin and trace mineral premix ${ }^{1,2}$ & 0.26 & 0.20 & 0.16 & 0.26 & 0.20 & 0.16 \\
\hline Phytase $^{3}$ & 0.08 & 0.08 & 0.05 & 0.08 & 0.08 & 0.05 \\
\hline L-Lys $\mathrm{HCl}$ & 0.29 & 0.30 & 0.32 & 0.29 & 0.30 & 0.32 \\
\hline DL-Met & 0.05 & 0.05 & 0.01 & 0.05 & 0.05 & 0.01 \\
\hline L-Thr & 0.09 & 0.08 & 0.10 & 0.09 & 0.08 & 0.10 \\
\hline Titanium dioxide ${ }^{4}$ & - & - & 0.50 & - & - & 0.50 \\
\hline \multicolumn{7}{|l|}{ Calculated analysis } \\
\hline \multicolumn{7}{|l|}{ Standard ileal digestible (SID) AA, \% } \\
\hline Lys & 0.94 & 0.81 & 0.71 & 0.94 & 0.81 & 0.71 \\
\hline Ile:Lys & 66 & 65 & 63 & 68 & 67 & 67 \\
\hline Met:Lys & 31 & 30 & 30 & 30 & 30 & 30 \\
\hline Met + Cys:Lys & 62 & 63 & 66 & 62 & 64 & 66 \\
\hline Thr:Lys & 63 & 63 & 66 & 62 & 63 & 66 \\
\hline Trp:Lys & 23.5 & 24.0 & 24.3 & 22.1 & 22.1 & 22.1 \\
\hline Val:Lys & 70 & 70 & 70 & 74 & 75 & 75 \\
\hline Total Lys, \% & 1.05 & 0.91 & 0.80 & 1.05 & 0.91 & 0.80 \\
\hline $\mathrm{ME},{ }^{5} \mathrm{kcal} / \mathrm{kg}$ & 3,233 & 3,240 & 3,240 & 3,286 & 3,299 & 3,302 \\
\hline $\mathrm{NE},{ }^{6} \mathrm{kcal} / \mathrm{kg}$ & 2,422 & 2,455 & 2,475 & 2,519 & 2,559 & 2,587 \\
\hline SID Lys:ME, g/Mcal & 2.91 & 2.50 & 2.19 & 2.86 & 2.45 & 2.15 \\
\hline Available P, \% & 0.28 & 0.23 & 0.22 & 0.28 & 0.23 & 0.22 \\
\hline \multicolumn{7}{|l|}{ Chemical analysis, $\%^{7}$} \\
\hline $\mathrm{DM}$ & 89.8 & 90.5 & 90.0 & 91.4 & 91.5 & 90.4 \\
\hline $\mathrm{CP}$ & 20.3 & 18.3 & 16.0 & 19.6 & 17.5 & 15.4 \\
\hline $\mathrm{ADF}$ & 2.5 & 2.3 & 1.9 & 3.0 & 2.9 & 2.2 \\
\hline NDF & 7.7 & 7.3 & 6.9 & 8.6 & 8.4 & 7.6 \\
\hline $\mathrm{Ca}$ & 0.72 & 0.68 & 0.62 & 0.81 & 0.67 & 0.63 \\
\hline $\mathrm{P}$ & 0.50 & 0.43 & 0.45 & 0.50 & 0.42 & 0.41 \\
\hline Ether extract & 2.7 & 2.6 & 2.40 & 2.6 & 2.7 & 2.40 \\
\hline Ash & 3.8 & 3.4 & 3.7 & 4.1 & 3.6 & 3.5 \\
\hline Starch & 39.9 & 45.4 & 47.4 & 41.8 & 44.7 & 49.3 \\
\hline
\end{tabular}

${ }^{1}$ Provided, per kilogram of premix, 4,409,200 IU vitamin A, 551,150 IU vitamin $\mathrm{D}_{3}, 17,637 \mathrm{IU}$ vitamin E, 1,764 mg vitamin $\mathrm{K}, 3,307 \mathrm{mg}$ riboflavin, $11,023 \mathrm{mg}$ pantothenic acid, $19,841 \mathrm{mg}$ niacin, and $15.4 \mathrm{mg}$ vitamin $\mathrm{B}_{12}$.

${ }^{2}$ Provided, per kilogram of premix, $26.5 \mathrm{~g} \mathrm{Mn}$ from manganese oxide, $110 \mathrm{~g}$ Fe from iron sulfate, $110 \mathrm{~g} \mathrm{Zn}$ from zinc sulfate, $11 \mathrm{~g}$ Cu from copper sulfate, $198 \mathrm{mg}$ I from calcium iodate, and $198 \mathrm{mg}$ Se from sodium selenite.

${ }^{3}$ Phyzyme 600 (Danisco Animal Nutrition, St. Louis, MO) provided 450.3 phytase units $/ \mathrm{kg}$ feed, with a release of $0.11 \%$ available P.

${ }^{4}$ Titanium was included in the Phase 3 diet as an indigestible marker and was fed for the first $7 \mathrm{~d}$ of the phase at a level of $0.5 \%$ at the expense of corn.

${ }^{5} \mathrm{NRC}, 2012$.

${ }^{6}$ Sauvant et al., 2004.

${ }^{7} \mathrm{~A}$ composite sample consisting of 6 subsamples was used for analysis. 
Table 4. Physical analysis of diets and wheat, Exp. $1^{1,2}$

\begin{tabular}{|c|c|c|c|}
\hline \multirow[b]{2}{*}{ Item } & \multicolumn{3}{|c|}{ Particle size, $\mu \mathrm{m}$} \\
\hline & 728 & 579 & 326 \\
\hline \multicolumn{4}{|l|}{ Wheat } \\
\hline Particle size (no flow agent $)^{3}, \mu \mathrm{m}$ & 728 & 579 & 326 \\
\hline Particle size (with flow agent), $\mu \mathrm{m}$ & 714 & 554 & 284 \\
\hline Bulk density, $g / L$ & 767 & 767 & 763 \\
\hline Angle of repose, ${ }^{\circ}$ & 42.4 & 45.8 & 50.9 \\
\hline \multicolumn{4}{|l|}{$\operatorname{Diet}^{4}$} \\
\hline Bulk density, $\mathrm{g} / \mathrm{L}$ & 765 & 763 & 733 \\
\hline Particle size (no flow agent), $\mu \mathrm{m}$ & 650 & 504 & 374 \\
\hline Angle of repose, ${ }^{\circ}$ & 44.7 & 46.4 & 50.7 \\
\hline \multicolumn{4}{|c|}{$\begin{array}{l}{ }^{1} \text { A composite sample consisting of } 6 \text { subsamples was used for analysis. } \\
{ }^{2} \text { All treatments were analyzed and values were averaged as all treat- } \\
\text { ments were identically formulated. }\end{array}$} \\
\hline \multicolumn{4}{|c|}{$\begin{array}{l}{ }^{3} \text { Particle sizes were determined using Tyler sieves, with numbers } 6,8,10 \text {, } \\
14,20,28,35,48,65,100,150,200 \text {, and } 270 \text { and a pan. A Ro-Tap shaker (W.S. } \\
\text { Tyler, Mentor, OH) was used to sift the } 100 \text {-g samples for } 10 \text { min. Particle } \\
\text { sizes were run with and without flow agent at an inclusion level of } 0.5 \mathrm{~g} \text {. }\end{array}$} \\
\hline
\end{tabular}

winter wheat. Finally, dietary treatments did not affect any carcass characteristics; however, feed efficiency on a carcass weight basis tended to be improved $(P<$ $0.10)$ when hard red winter wheat was fed compared with when soft white winter wheat was fed.

\section{DISCUSSION}

Although wheat production has decreased in recent years in the United States, it is still used in livestock diets domestically and across the world (USDA, 2016). Wheat can be categorized into 5 main classifications including hard red winter, hard red spring, soft red winter, white, and durum (USDA, 2013). Of these, hard red winter wheat represents $40 \%$ of total production in the United States in a given year, making it the most common wheat used for livestock diets (USDA, 2013). White wheat, although less common, is more widely grown in the western United States (USDA, 2013) and, therefore, is used for swine located in that region.

Previous work has shown the concentration of energy in wheat to be 91 to $97 \%$ that of corn and the concentration of AA to be greater than that of corn (Stein et al., 2010). In numerous studies when diets were balanced for dietary energy and AA, wheat- and corn-based diets produced similar growth performance and carcass characteristics when fed during the nursery phase (Erickson et al., 1980) or the finisher phase (Han et al., 2005). This suggests corn can be replaced with wheat in diet formulation with few or no negative effects on performance. Jha et al. (2011) fed 6 Canadian wheat varieties for 21 $\mathrm{d}$ to weanling pigs and found that wheat variety had no effect on ADG, ADFI, or G:F. They also noted no difference for pelleting throughput or PDI between the 6 wheat varieties. Bhatty et al. (1974) fed 17 cultivars of hard and soft spring wheat and found that soft white had a greater GE and less fiber than hard red wheat. In the current study, pigs fed hard red winter wheat had increased ADG and ADFI compared with those fed soft white winter wheat. Values for feed per kilogram carcass tended to be poorer for pigs fed soft white winter wheat than hard red winter wheat in the current experiment, suggesting that the source of soft white winter wheat used may have been slightly lower in energy than what would normally be expected (Sauvant et al., 2004).

In Exp. 1, particle size reduction of hard red winter wheat from 728 to $326 \mu \mathrm{m}$ initially resulted in reduced ADFI and numerically lower ADG. However, pigs appeared to adjust to the finely ground diets during the second half of the trial, as reducing wheat particle size improved $\mathrm{ADG}$ and G:F, which led to similar improvements

Table 5. Physical analysis of diets and wheat, Exp. $2^{1,2}$

\begin{tabular}{|c|c|c|c|c|c|c|}
\hline \multirow[b]{3}{*}{ Item } & \multicolumn{6}{|c|}{ Wheat source and particle size, $\mu \mathrm{m}$} \\
\hline & \multicolumn{3}{|c|}{ Hard red winter wheat } & \multicolumn{3}{|c|}{ Soft white winter wheat } \\
\hline & 693 & 465 & 245 & 710 & 402 & 258 \\
\hline \multicolumn{7}{|l|}{ Wheat } \\
\hline Particle size (no flow agent) ${ }^{3}, \mu \mathrm{m}$ & 693 & 465 & 245 & 710 & 402 & 258 \\
\hline Particle size (with flow agent), $\mu \mathrm{m}$ & 631 & 415 & 201 & 638 & 341 & 210 \\
\hline Bulk density, $g / L$ & 1,134 & 1,224 & 1,088 & 1,192 & 1,133 & 1,125 \\
\hline Angle of repose, ${ }^{\circ}$ & 45.8 & 49.5 & 50.8 & 43.6 & 58.2 & 58.1 \\
\hline \multicolumn{7}{|l|}{ Diet $^{4}$} \\
\hline Bulk density, g/L & 870 & 860 & 875 & 853 & 876 & 883 \\
\hline Pellet durability index, $\%$ & 74.2 & 81.2 & 88.5 & 48.7 & 50.9 & 54.5 \\
\hline Pellet fines, $\%$ & 26.9 & 22.9 & 24.0 & 24.1 & 27.2 & 22.2 \\
\hline
\end{tabular}


Table 6. Feed manufacturing electrical consumption and throughput, Exp. $2^{1}$

\begin{tabular}{|c|c|c|c|c|c|c|}
\hline \multirow[b]{3}{*}{ Item } & \multicolumn{6}{|c|}{ Wheat source and particle size, $\mu \mathrm{m}$} \\
\hline & \multicolumn{3}{|c|}{ Hard red winter wheat } & \multicolumn{3}{|c|}{ Soft white winter wheat } \\
\hline & 693 & 465 & 245 & 710 & 402 & 258 \\
\hline \multicolumn{7}{|l|}{ Wheat grinding } \\
\hline $\mathrm{kW}^{2}$ & 8.4 & 9.3 & 11.0 & 7.6 & 8.5 & 8.6 \\
\hline $\mathrm{kWh}^{3}$ & 7.0 & 7.0 & 7.9 & 4.4 & 4.9 & 5.0 \\
\hline Throughput, $\mathrm{t} / \mathrm{h}$ & 4.1 & 3.6 & 3.3 & 4.1 & 4.3 & 4.7 \\
\hline $\mathrm{kWh} / \mathrm{t}$ & 2.0 & 2.6 & 3.3 & 1.6 & 2.0 & 2.1 \\
\hline \multicolumn{7}{|l|}{ Pelleting } \\
\hline $\mathrm{kW}$ & 21.0 & 20.6 & 20.6 & 22.7 & 22.8 & 22.6 \\
\hline $\mathrm{kWh}$ & 12.3 & 12.7 & 14.1 & 14.9 & 13.8 & 13.6 \\
\hline Throughput, $\mathrm{t} / \mathrm{h}$ & 1.2 & 1.1 & 1.0 & 1.2 & 1.2 & 1.2 \\
\hline $\mathrm{kWh} / \mathrm{t}$ & 17.5 & 18.7 & 20.6 & 18.9 & 19.0 & 18.8 \\
\hline
\end{tabular}

${ }^{1}$ Voltage was recorded during each manufacturing run and then averaged across the dietary phases

${ }^{2} \mathrm{~kW}$ was calculated by the formula $\mathrm{kW}=$ amperage $\times$ voltage $/ 1,000$.

${ }^{3} \mathrm{kWh}$ was calculated by the formula $\mathrm{kWh}=\mathrm{kW} \times$ hours used.

in overall G:F. Seerley et al. (1988) also fed varying particle sizes of wheat to finishing pigs but found results contrasting to those reported herein. Their results suggest that a larger particle size $(1,780 \mu \mathrm{m})$ increased ADG in the finishing period compared with finely ground (890 to $1,410 \mu \mathrm{m}$ ) wheat. The improvement in ADG with coarsely ground wheat is difficult to explain given that G:F was also numerically improved with the coarsely ground wheat in their study. Mavromichalis et al. (2000) conducted 2 separate experiments exploring particle size of wheat. In their first experiment, finishing pigs were fed wheat ground to either 1,300 or $600 \mu \mathrm{m}$. Pigs fed the finely ground wheat had improved G:F. In their second experiment, pigs were fed wheat ground to 600 or $400 \mu \mathrm{m}$. Again, pigs fed the finely ground wheat had improved G:F but also had a greater incidence of stomach ulcers.

In the current study, as hard red winter wheat was ground from coarse to fine in mash diets, pigs had improved DM and GE digestibility. This agrees with Choct et al. (2004), who conducted a weanling pig trial to determine the effect of wheat particle size on nutrient digestibility. The study used both a hammer mill and a roller mill to reduce wheat particle size. Fine, medium, and coarse ground treatments were created for each respective milling apparatus. Digestibility for GE was improved as particle size was reduced regardless of the processing method. In a similarly designed study by Mavromichalis et al. (2000), the apparent digestibility of DM and $\mathrm{N}$ was improved as wheat particle size was reduced when comparing 1,300- to $600-\mu \mathrm{m}$ wheat and 600 - to $400-\mu \mathrm{m}$ wheat. l'Anson et al. (2012) observed that grinding wheat from 760 to $664 \mu \mathrm{m}$ did not affect any growth criteria but did improve GE digestibility. The $96-\mu \mathrm{m}$ decrease in particle size may not have been large enough to elicit a growth re-
Table 7. Effects of wheat particle size on finishing pig performance, Exp. $1^{1}$

\begin{tabular}{lccccccc}
\hline \hline & \multicolumn{3}{c}{ Wheat particle size, $\mu \mathrm{m}$} & & \multicolumn{2}{c}{ Probability, $P<$} \\
\cline { 2 - 3 } Item & 728 & 579 & 326 & SEM & Linear & Quadratic \\
\hline $\mathrm{d} 0$ to 40 & & & & & & \\
ADG, kg & 0.92 & 0.93 & 0.90 & 0.01 & 0.274 & 0.313 \\
ADFI, kg & 2.29 & 2.24 & 2.20 & 0.03 & 0.035 & 0.713 \\
G:F & 0.400 & 0.413 & 0.409 & 0.003 & 0.038 & 0.006 \\
d 40 to 83 & & & & & & \\
ADG, kg & 0.92 & 0.90 & 0.95 & 0.01 & 0.013 & 0.042 \\
ADFI, kg & 2.87 & 2.80 & 2.84 & 0.04 & 0.608 & 0.196 \\
G:F & 0.319 & 0.322 & 0.336 & 0.003 & 0.001 & 0.406 \\
d 0 to 83 & & & & & & \\
ADG, kg & 0.92 & 0.91 & 0.93 & 0.01 & 0.415 & 0.571 \\
ADFI, kg & 2.59 & 2.53 & 2.53 & 0.03 & 0.166 & 0.319 \\
G:F & 0.354 & 0.361 & 0.367 & 0.003 & 0.002 & 0.464 \\
Digestibility & & & & & & \\
DM, \% & 89.0 & 91.2 & 91.5 & 0.7 & 0.019 & 0.129 \\
GE, \% & 65.5 & 70.3 & 73.5 & 1.9 & 0.004 & 0.387 \\
BW, kg & & & & & & \\
d 0 & 43.8 & 43.8 & 43.8 & 0.51 & 0.996 & 0.998 \\
d 40 & 80.4 & 80.7 & 79.9 & 0.83 & 0.660 & 0.627 \\
d 83 & 119.8 & 119.5 & 121.1 & 1.14 & 0.366 & 0.596 \\
\hline
\end{tabular}

${ }^{1}$ A total of 288 pigs $($ PIC $327 \times 1050)$ were used, with 12 pens per treatment and 8 pigs per pen.

${ }^{2}$ Fecal samples were taken on $\mathrm{d} 67$ of the study via rectal massage from 2 pigs per pen.

sponse, given the replication in the study, although differences in digestibility were realized. In general, it appears that as particle size is reduced, the nutrient digestibility improves in diets fed in meal form.

Conversely, in Exp. 2, nutrient digestibility was not improved as particle size was reduced when diets were fed in pelleted form. This is in contrast to work by Healy et al. (1994), who found improved digestibility of $\mathrm{N}$, $\mathrm{DM}$, and GE when corn and hard and soft sorghum with decreasing particle sizes $(900,700,500$, and $300 \mu \mathrm{m})$ were fed to weanling pigs in pelleted form. These differing results may be a result of the different grains fed, the different pig weight ranges used, or potential lack of precision due to sampling only once from 2 pigs per pen. The smaller particle sizes used in the current experiment compared with larger particle sizes being fed in the Healy et al. (1994) experiment also may have influenced the results. Therefore, our data would suggest that in pelleted diets, the improvement due to particle size reduction for nutrient digestibility may diminish as particle size is reduced below approximately $500 \mu \mathrm{m}$.

In tandem with improved digestibility, improvements in growth performance have been associated with decreased particle size of cereal when diets are fed in meal form (Hedde et al., 1985; Wu, 1985; Wondra et al., 1995). However, data is limited on the effect of particle size of wheat in pelleted diets with finishing pigs. 
Table 8. Effects of wheat source and particle size of pelleted diets on finishing pig growth performance and carcass characteristics, Exp. $2^{1}$

\begin{tabular}{|c|c|c|c|c|c|c|c|c|c|}
\hline \multirow[b]{3}{*}{ Item } & \multicolumn{6}{|c|}{ Wheat source and particle size, $\mu \mathrm{m}$} & \multirow[b]{3}{*}{ SEM } & \multirow{2}{*}{\multicolumn{2}{|c|}{ Probability, $P<$}} \\
\hline & \multicolumn{3}{|c|}{ Hard red winter } & \multicolumn{3}{|c|}{ Soft white winter } & & & \\
\hline & 693 & 465 & 245 & 710 & 402 & 258 & & $\begin{array}{l}\text { Quadratic particle } \\
\text { size } \times \text { source }^{2}\end{array}$ & $\begin{array}{c}\text { Source } \\
\text { main effect }\end{array}$ \\
\hline$\overline{\mathrm{ADG}, \mathrm{kg}}$ & 1.03 & 1.01 & 1.03 & 0.99 & 1.00 & 0.97 & 0.013 & 0.055 & 0.004 \\
\hline ADFI, kg & 2.67 & 2.59 & 2.66 & 2.56 & 2.58 & 2.54 & 0.035 & 0.060 & 0.003 \\
\hline G:F & 0.384 & 0.388 & 0.387 & 0.388 & 0.389 & 0.384 & 0.0029 & 0.881 & 0.941 \\
\hline Initial BW, kg & 43.4 & 43.4 & 43.4 & 43.4 & 43.4 & 43.4 & 3.75 & 0.989 & 0.978 \\
\hline Final BW, kg & 127.3 & 125.6 & 127.9 & 125.3 & 125.7 & 123.2 & 3.19 & 0.141 & 0.074 \\
\hline \multicolumn{10}{|l|}{ Digestibility } \\
\hline DM, \% & 88.0 & 87.0 & 87.7 & 85.1 & 87.7 & 85.8 & 0.79 & 0.040 & 0.048 \\
\hline GE, $\%$ & 66.3 & 64.5 & 68.3 & 64.9 & 67.5 & 62.3 & 1.95 & 0.041 & 0.360 \\
\hline \multicolumn{10}{|l|}{ Carcass traits } \\
\hline Feed/carcass gain 3 & 1.66 & 1.63 & 1.65 & 1.71 & 1.70 & 1.67 & 0.029 & 0.418 & 0.065 \\
\hline $\mathrm{HCW}, \mathrm{kg}$ & 91.77 & 90.31 & 91.36 & 90.44 & 91.10 & 89.42 & 1.439 & 0.302 & 0.479 \\
\hline Carcass yield, $\%$ & 72.9 & 72.8 & 73 & 73.1 & 73.1 & 73.0 & 0.15 & 0.234 & 0.167 \\
\hline Backfat, mm & 18.96 & 19.28 & 19.62 & 19.93 & 19.59 & 19.17 & 0.434 & 0.792 & 0.431 \\
\hline Loin depth, mm & 58.71 & 57.97 & 57.14 & 57.75 & 58.21 & 56.40 & 1.300 & 0.426 & 0.445 \\
\hline Percentage lean, $\%$ & 52.8 & 52.6 & 52.4 & 52.4 & 52.5 & 52.5 & 0.21 & 0.859 & 0.397 \\
\hline Jowl iodine value, $\mathrm{mg} / 100 \mathrm{~g}$ & 68.6 & 69.0 & 69.1 & 68.3 & 68.6 & 68.4 & 0.43 & 0.945 & 0.210 \\
\hline
\end{tabular}

In Exp. 2, reducing particle size of either wheat source in pelleted diets had no effect on performance of finishing pigs. Murphy et al. (2009) conducted a similar experiment with wheat diets finely ground to either 639 or $552 \mu \mathrm{m}$, where again all diets were fed in pelleted form. When wheat was finely ground, it tended to improve G:F; however, this may have been a result of the improved pellet quality of the finely ground wheat diets and not a direct effect of the decreased particle size. De Jong et al. (2012) investigated the effects of particle size of pelleted diets in nursery pigs using corn ground to 638 or $325 \mu \mathrm{m}$, respectively. When corn was finely ground to $325 \mu \mathrm{m}$ and fed in pelleted form, there was no effect of particle size on growth performance of the nursery pigs. Pelleting has been shown to improve diet digestibility (Graham et al., 1989; Wondra et al., 1995; Xing et al., 2004), which, in addition to the current data, might suggest that a diet's digestibility may reach a theoretical "ceiling" when pelleting is used and additional effects of diet particle size may not be realized. This might suggest that particle size reduction in pelleted diets may be advantageous only when grain is coarsely ground $(>500 \mu \mathrm{m})$ and not when grain is finely ground $(<500 \mu \mathrm{m})$. Lahaye et al. (2008) also found that reducing the particle size of wheat from 1,000 to 500 $\mu \mathrm{m}$ improved DE, OM, and DM digestibility when fed in meal form but that pelleting did not further improve digestibility. This further demonstrates that pelleting and fine grinding of wheat diets does not produce an additive improvement in G:F.

Feed processing technologies have the ability to improve feed efficiency and growth in pigs, but they can also potentially increase the feed mill's cost of production. The improved animal performance needs to be balanced with the increased cost of production and reductions in feed mill throughput to justify the additional grain or complete diet processing. In Exp. 2, grinding hard red or soft white winter wheat from approximately 600 to approximately $200 \mu \mathrm{m}$ increased kilowatts and kilowatt hours required for grinding and kilowatt hours per tonne. In addition, fine grinding reduced throughput by 0.08 and $0.06 \mathrm{t} / \mathrm{h}$ for hard red and soft white winter wheat, respectively. This was similar to results reported by Healy et al. (1994), who also reported increased kilowatt usage as particle size of either corn or sorghum was reduced from 900 to $300 \mu \mathrm{m}$. Paulk et al. (2015) also reported increased electrical usage as sorghum was ground from 724 to $319 \mu \mathrm{m}$. Both, Paulk et al. (2015) and Healy et al. (1994) reported reduced rates of production as grains were more finely ground. The reduced production rate and increased kilowatt usage during grinding, especially at the finer grinds, will increase the cost of manufacturing at the feed mill.

In conclusion, fine grinding hard red winter wheat improved G:F when diets were fed in meal form. When hard red winter or soft white winter wheat diets were 
finely ground and fed in pelleted form, no effect of particle size on growth was observed. It appears that very fine grinding $(<500 \mu \mathrm{m})$ is not warranted if diets are to be pelleted, except as a means to improve pellet quality.

\section{LITERATURE CITED}

American Society of Agricultural Engineers (ASAE). 1987. Wafers, pellets, and crumbles-Definitions and methods for determining density, durability, and moisture content. ASAE Standard S269.3. In: Agricultural Engineers Yearbook of Standards. American Society of Agricultural Engineers, St. Hoseph, MI. p. 318.

American Society of Agricultural Engineers (ASAE). 2008. Method of determining and expressing fineness of feed materials by sieving. ASAE Standard S319.4. In: Agricultural Engineers Yearbook of Standards. American Society of Agricultural Engineers, St. Joseph, MO. p. 1-7.

AOAC. 2006. Official methods of analysis. 18th ed. AOAC Int., Washington, DC.

Appel, W. B. 1994. Physical properties of feed ingredients. In: R. R. McEllhiney, editor, Feed manufacturing technology. 4th ed. Amer. Feed Industry Assoc., Inc., Arlington, VA. p. 558-562.

Bhatty, R. S., G. I. Christison, F. W. Sosulski, B. L. Harvey, G. R. Hughes, and J. D. Berdahl. 1974. Relationship of various physical and chemical characters to digestible energy in wheat and barley cultivars. Can. J. Anim. Sci. 54:419-427. doi:10.4141/ cjas74-057

Choct, M., E. A. D. Selby, D. J. Cadogan, and R. G. Campbell. 2004. Effects of particle size, processing, and dry or liquid feeding on performance of piglets. Aust. J. Agric. Res. 55:237-245. doi:10.1071/AR03105

Clementson, C. L., K. E. Ileleji, and K. Rosentrater. 2010. Evaluation of measurement procedures used to determine the bulk density of distillers dried grains with solubles (DDGS). Trans. ASABE 53:485-490.

Cocciardi, R. A., J. M. Benz, H. Li, S. S. Dritz, J. M. DeRouchey, M. D. Tokach, J. L. Nelssen, R. D. Goodband, and A. W. Duttlinger. 2009. Analysis of iodine value in pork fat by Fourier transform near infrared spectroscopy for pork fat quality assessment. J. Anim. Sci. 87(Suppl. 2):579. (Abstr.)

De Jong, J. A., J. M. DeRouchey, M. D. Tokach, R. D. Goodband, S. S. Dritz, J. L. Nelssen, and L. McKinney. 2012. Effects of corn particle size, complete diet grinding, and diet form on finishing pig growth performance, caloric efficiency, carcass characteristics and economics. J. Anim. Sci. 91(Suppl. 2):70. (Abstr.)

Erickson, J. P., E. R. Miller, G. M. Hill, J. R. Black, D. M. Bebiak, and P. K. Ku. 1980. Wheat versus corn in pelleted and meal swine diets. J. Anim. Sci. 51:1065-1069.

Graham, H., J. G. Fadel, C. W. Newman, and P. K. Newman. 1989. Effect of pelleting and $\beta$-glucanase supplementation on the ileal and fecal digestibility of a barley-based diet in the pig. J. Anim. Sci. 67:1293-1298.

Han, Y., J. W. Soita, and P. A. Thacker. 2005. Performance and carcass composition of growing finishing pigs fed wheat or corn-based diets. Asian-Australas. J. Anim. Sci. 18:704-710.

Hancock, J. D., and K. C. Behnke. 2001. Use of ingredient and diet processing technologies (grinding, mixing, pelleting, and extruding) to produce quality feeds for pigs. In: A. J. Lewis and L. L. Southern, editors, Swine nutrition. CRC Press, Boca Raton, FL. p. 469-497.

Healy, B. J., J. D. Hancock, G. A. Kennedy, P. J. Bramel-Cox, K. C. Behnke, and R. H. Hines. 1994. Optimum particle size of corn and hard and soft sorghum for nursery pigs. J. Anim. Sci. 72:2227-2236.

Hedde, R. D., T. O. Lindsey, R. C. Parish, H. D. Daniels, E. A. Morgenthien, and H. B. Lewis. 1985. Effect of diet particle size and feeding of HZ-receptor antagonists on gastric ulcers in swine. J. Anim. Sci. 61:179-186.
International Organization for Standardization (ISO). 2004. Animal feeding stuffs - Enzymatic determination of total starch content. Method 15914. International Organization for Standardization, Geneva Switzerland. https://www.iso.org/obp/ ui/\#iso:std:iso:15914:ed-1:v1:en

Jha, R., D. N. Overend, P. H. Simmins, D. Hickling, and R. T. Zijlstra. 2011. Chemical characteristics, feed processing quality, growth performance and energy digestibility among wheat classes in pelleted diets fed to weaned pigs. Anim. Feed Sci. Technol. 170:78-90. doi:10.1016/j.anifeedsci.2011.08.006

Kong, C., and O. Adeola. 2014. Evaluation of amino acid and energy utilization in feedstuff for swine and poultry diets. AsianAustralas. J. Anim. Sci. 27:917-925.

Lahaye, L., P. Ganier, J. N. Thibault, Y. Riou, and B. Seve. 2008. Impact of wheat grinding and pelleting in a wheat-rapeseed meal diet on amino acid ileal digestibility and endogenous losses in pigs. Anim. Feed Sci. Technol. 141:287-305. doi:10.1016/j.anifeedsci.2007.06.016

l'Anson, K., M. Choct, and P. H. Brooks. 2012. The influence of particle size and processing method for wheat-based diets, offered in dry or liquid form, on growth performance and diet digestibility in male weaner pigs. Anim. Prod. Sci. 52:899-904. doi:10.1071/ AN12082

Mavromichalis, J., D. Hancock, B. W. Senne, T. L. Gugle, G. A. Kennedy, R. H. Hines, and C. L. Wyatt. 2000. Enzyme supplementation and particle size of wheat in diets for nursery and finishing pigs. J. Anim. Sci. 78:3086-3095.

Murphy, A., C. Collins, A. Phillpotts, A. Bunyan, and D. Henman. 2009. Influence of hammermill screen size and grain source (wheat or sorghum) on the growth performance of male grower pigs. Project IB-107. Pork CRC, Willaston, SA, Australia.

NRC. 2012. Nutrient requirements of swine. 11th ed. Natl. Acad. Press, Washington, DC.

Paulk, C. B., J. D. Hancock, A. C. Fahrenholz, J. M. Wilson, L. J. Mckinney, and K. C. Behnke. 2015. Effects of sorghum particle size on milling characteristics and growth performance in finishing pigs. Anim. Feed Sci. Technol. 202:75-80. doi:10.1016/j. anifeedsci.2015.01.017

Sauvant, D., J.-M. Perez, and G. Tran, editors. 2004. Tables of composition and nutritional value of feed materials: Pig, poultry, sheep, goats, rabbits, horses, and fish. Wageningen Academic Publishers, Wageningen, the Netherlands. INRA, editors, Paris, France.

Seerley, R. W., W. L. Vandergrift, and O. M. Hale. 1988. Effect of particle size of wheat on performance of nursery, growing and finishing pigs. J. Anim. Sci. 66:2484-2489.

Stark, C. R., K. C. Behnke, J. D. Hancock, S. L. Traylor, and R. H. Hines. 1994. Effect of diet form and fines in pelleted diets on growth performance of nursery pigs. J. Anim. Sci. 72(Suppl. 1):24. (Abstr.)

Stein, H. H., A. A. Pahm, and J. A. Roth. 2010. Feeding wheat to pigs. Swine Focus 002:1-8

USDA. 2013. US wheat classes. http:/www.ers.usda.gov/topics/ crops/wheat/background.aspx. (Accessed 7 July 2015.)

USDA. 2016. World agricultural supply and demand estimates. http:// www.usda.gov/oce/commodity/wasde/latest.pdf. (Accessed 6 May 2016.)

Van Soest, P. J. 1963. Use of detergents in the analysis of fibrous feeds. II. A rapid method for determination of fiber and lignin. J. Assoc. Off. Agric. Chem. 46:829-835.

Wondra, K. J., J. D. Hancock, K. C. Behnke, R. H. Hines, and C. R. Stark. 1995. Effects of particle size and pelleting on growth performance, nutrient digestibility, and stomach morphology in finishing pigs. J. Anim. Sci. 73:757-763.

Wu, J. F. 1985. Effects of particle size of corn, sorghum grain, and wheat on pig performance and nutrient digestibility. $\mathrm{PhD}$ Diss., Kansas State Univ., Manhattan, KS.

Xing, J. J., E. van Heugten, D. F. Li, K. J. Touchette, J. A. Coalson, R. L. Odgaard, and J. Odle. 2004. Effects of emulsification, fat encapsulation, and pelleting on weanling pig performance and nutrient digestibility. J. Anim. Sci. 82:2601-2609. 